\title{
Tactical Urbanism as an Approach to Reuse Residual Spaces
}

\author{
Rania El Messeidy
}

\author{
Lecturer, Department of Architecture, Faculty of Engineering, October University for Modern Sciences and Arts \\ (MSA) University, $6^{\text {th }}$ of October, Cairo, Egypt \\ rhamdi@msa.eun.eg rania_h2000@yahoo.com
}

\begin{abstract}
Most cities around the world have residual spaces. Perhaps no city has no residual spaces. The residual spaces are areas in the city layout that have no real benefit to the community. These spaces appear as a result of the planning process. They are located in places such as between streets, between buildings and under bridges. Sometimes they are also called in-between spaces and lost spaces. These residual spaces seem to be a burden on city planning as they turn into abandoned or informal activities. On the other hand, they may represent a source of income and allow for community participation, which in turn could be a part of the sustainable development of cities. Therefore, these areas could be exploited and oriented towards community serving and problem-solving such as unemployment problem in developing countries in particular. In other words, these spaces have potentials that can be exploited through reuse. Tactical urbanism is a trend that seeks to reuse urban spaces and transform them into development opportunities that benefit society. Tactical urbanism mainly relies on low-cost, service-oriented projects in the community. This paper highlights the reuse of residual spaces through the adoption of tactical urbanism as an approach. In this sense, the paper identifies the residual spaces, their classification and their potentials. The paper then proceeds into determining the tactical urbanism by definition, its importance and how it works. In the analytical part, the paper investigates a local case study, "306 street" project in the Dokki area, Egypt. The study concludes the importance of reusing the residual spaces using tactical urbanism approach and their contribution to community development. The study ends with a set of recommendations on various levels.
\end{abstract}

Keywords: Residual Spaces, Tactical Urbanism, Potentials, Communities, Cities.

\section{INTRODUCTION}

Urban spaces are external environments which make people feel comfort. They are essential to city' life, as they permit the society to interact, strengthen the identities of communities and make the population' life better. Urban spaces' success depends on the efficiency and attractiveness of the overall user design [1].

Urban public spaces are an assisting value for the city that wants to attract businesses or workers. Cities are increasingly competing for foreign investment. When urban public spaces are well designed and managed, the city becomes more competitive [2]. In this sense, urban areas can be seen as a cause and a solution to the current environmental crisis. As the population of large cities grows, so does the demand for increased development. Tomorrow's cities must also manage limited urban space and resources, and constantly improve the current urban environment. One of the ways is to reuse areas that are not being used effectively at present [3]. Solutions for this problem are often found in residual spaces, which can provide adequate and immediate opportunities for linking and using newly adapted open spaces. Residual areas are often publicly owned and of little value, usually regarded as a waste or landfill, but they invite creative solutions [4] They are in every city, perceived as "lost spaces," uncomfortable corners, unwanted areas under heavy traffic intersections. In most cases, they are abandoned and maintenance-free [1].

City dwellers have long been practicing a form of tactical urban planning: reallocating unused spaces with temporary materials and transforming them into more dynamic public spaces. However, tactical urban planning has become a movement for several years. Disappointed by the slow, expensive and often exclusive approaches to project execution, professionals in the city noted that temporary interventions were an effective tactic to discover what worked and implement projects in the field. These temporary projects can help foster meaningful public participation and generate support for ongoing projects by allowing people to see what is possible instead of just seeing the reports. In Burlington, Vermont's Quick Build Program uses low-cost materials to test new design approaches and uses these demonstration projects to update street design standards [5]. Fig 1.

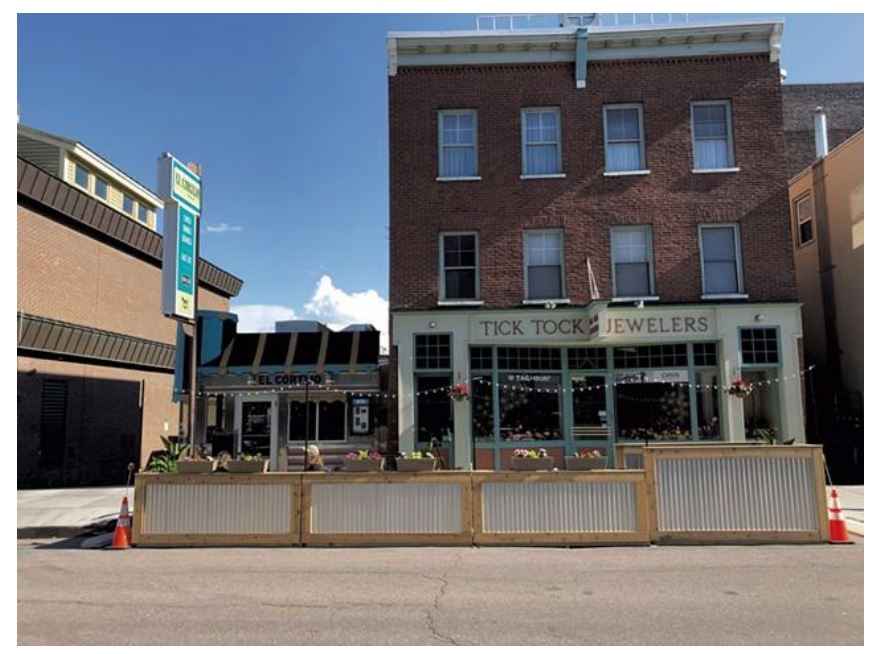

Figure 1. Use of low-cost materials to update street design of Burlington's El Cortijo Taqueria 
This paper highlights the reuse of residual spaces through the adoption of tactical urbanism as an approach. In this sense, the paper identifies the residual spaces, their classification and their potentials. The paper then proceeds into determining the tactical urbanism by definition, its importance and how it works. In the analytical part, the paper investigates a local case study, "306 street" project in the Dokki area, Egypt. The study concludes the importance of reusing the residual spaces using tactical urbanism approach and their contribution to community development. The study ends with a set of recommendations on various levels.

\section{RESIDUAL SPACES}

Urban spaces are what you see in the city, not only in terms of physical composition and urban structure, but also because of their perceptions of social, cultural, historical, political, economic and technological status through which the population can establish relations with the city.

The residual areas are those areas not designed in the urban planning. They could be a result of the separation of elements related to traffic and remain as small islands in the middle of the roads. However, given the circumstances and its transformation potential, it must be completely analyzed because of its potentials that could serve the city. Fig. 2 shows an example of a rest area in Mexico City equipped with a playground [6].

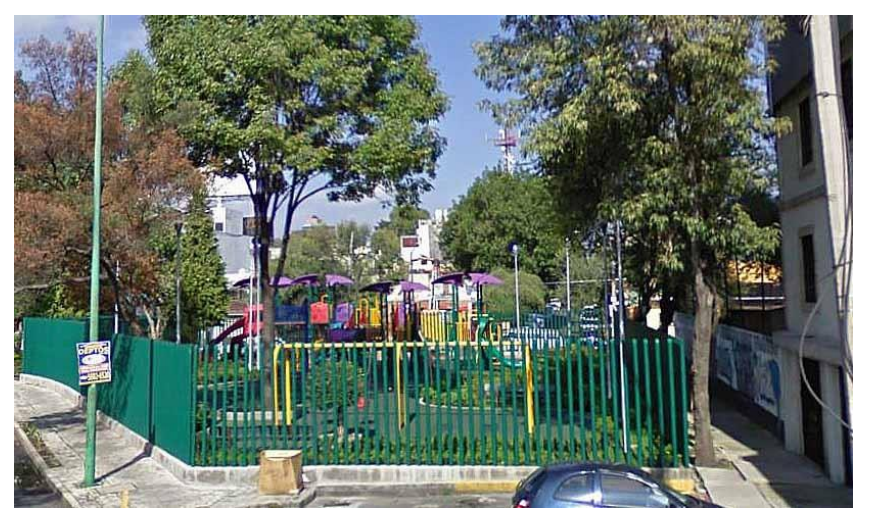

Figure 2. Rest area in Mexico City equipped with a playground Mexico City.

According to an investigation done by [1], residual spaces could be classified into four types: parking lots, alleys, median strips and underground corridors. Smart, so-called parklets have provided urban planners with an innovative way to clear the streets for pedestrians. Spreading safely, they enable people to sit, meet and interact with each other in places where parallel parking spaces are in front of selected companies. The alleys are residual parts mainly used as communication routes. Some additions such as technical facilities, plants and lighting could simply transform alleys into ecological, dynamic spaces. The median strips are paved or vegetarian plots that divide the corridors according to traffic. Finally, the underground corridors of the roads, are the areas where pedestrians and vehicles pass under a road. These corridors, which generally contain unused land, are cold, dark, frightening and ugly castles.

With a particular reference to the neighborhood context; residual space could be considered three types: "non-spaces," "leftover spaces" and "multipurpose spaces". Non-spaces are often located near car lanes and include intermediate strips along roads and highways. Leftover spaces are spaces created by intervening in a previously open space and includes unusual geometric spaces adjacent to intersections, underpasses, and traffic islands and are not connected to surrounding spaces. Multipurpose spaces are areas that become residual spaces for certain periods - as the case of parking lots that become empty after business hours [4].

The residual areas respond to shapes and dimensions according to their limitations (walls, roads, natural barriers, etc.), most of which are either occupied by planned plants or by spontaneous growth. The lack of maintenance in the residual spaces is more likely to affect specific interests as sellers, temporary accommodation, parking and others contribute to the gradual deterioration of these locations [6].

In the dictionary the word "residual" means "a remainder" or "remaining after a part is taken." In Finding Lost Space, Roger Trancik writes: "Generally speaking, lost spaces are the undesirable urban areas that are in need of redesign - anti spaces, making no positive contribution to the surrounding or users. They are ill-defined, without measurable boundaries, and fail to connect elements in a coherent way" [4].

Earlier, communities did not use residual spaces in a positive way. Today, cities around the world are slowly recognizing the potential of these spaces [1].

\section{POTENTIALS OF RESIDUAL SPACES}

They are corners and areas that are always found in urban tend to generate undesirable sections. These spaces overlap between neighboring organisms, which ultimately pose a problem for the urban fabric. Architects should emphasis more on its potentials as they could be reused providing solutions for other problems and issues in the society [30]. Fig. 3 Examples of residual spaces in cities.
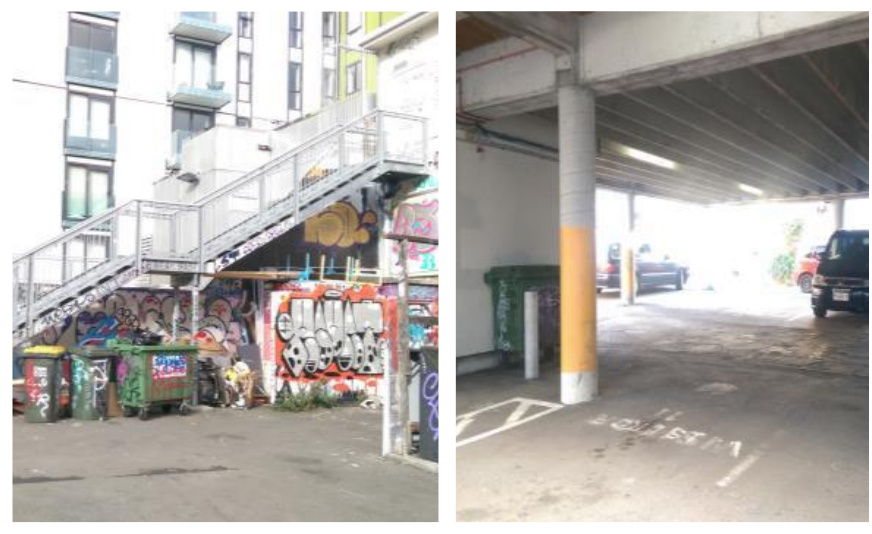

Figure. 3 Examples of residual spaces in cities.

Roger Transik was one of the first to write about lost or unmanaged places as he mentioned that these places were counter spaces within cities and did not contribute positively to surrounding spaces and, therefore, had to be redesigned [8, 9]. To a large extent, they are determined by researchers' understanding that they evaluate their estimates with respect to cause and effect metrics, ignoring the potential it offers and renewal opportunities. These unique spaces are a state in 
a particular place and time and must be handled properly when they are not full [9].

Tactical urbanism is a newly developed concept that often relies on cost-effective temporary interventions and little effort to improve the viability and aesthetics of local neighborhoods. Small scale and short - term interventions can lead to long - term changes, as this approach is "a thoughtful and incremental approach to change, to present local ideas for local planning challenges, short - term commitment and realistic expectations, low-risks, with possibly a high reward. Tactical approach provides adaptive and cost-effective processes that will transform the residual spaces using diversity of ideas [15].

These projects have become increasingly popular in recent years. Tactical urbanization, as in the tactics of improving the urban environment. These tactics have generally been replicable in all cities and, in some cases, have become a global phenomenon. These small interventions are characterized by their social and realistic goals [11].

\section{TACTICAL URBANISM: MOVEMENT AND THEORY}

Tactical urbanizm is the direction / movement that enters the area of "City Repair " and "DIY urbanism". They are often small projects, temporary, economical, quick to install and disassemble, participatory and oriented to solve community problems [29].

This concept goes back more than a century, when city dwellers faced the same concerns that dominated debates over today's cities. Open Streets (championed in Canada) date back to the Safe Streets for Play movements in New York at the beginning of the 20th century. Fig. 4 [13].

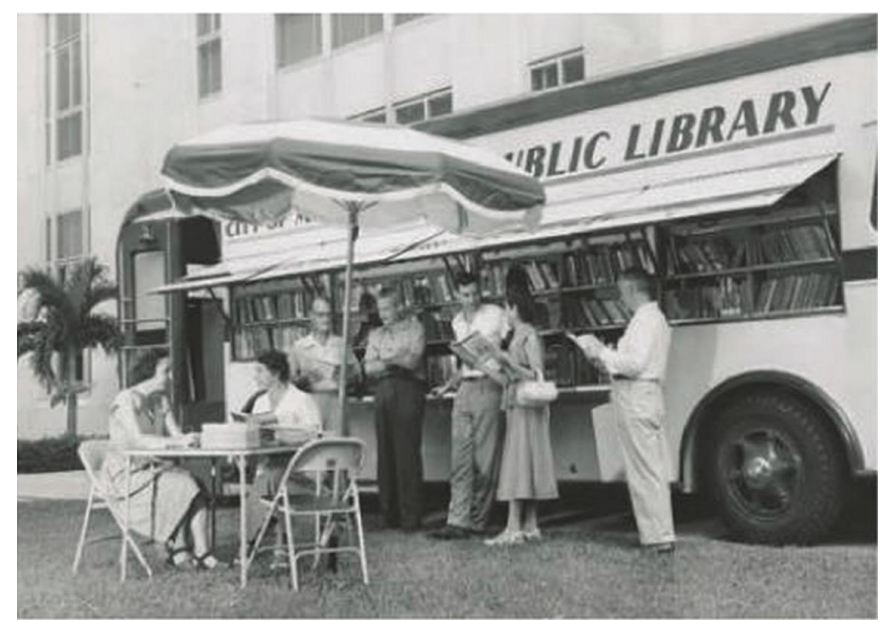

Figure 4. An early Bookmobile in New York City.

Les Bouquinistes in Paris, France, Fig 5, shows that tactical urbanism is not new. Since the sixteenth century, sellers of uncredited books have gathered on the banks of the successful sale on the Seine-Laksour [14, 13]. In 2007, the Bouquinistes region was declared a World Heritage Site by UNESCO, making this tactic the slowest example of tactical urbanization. Today les Bouquinistes become a UNESCO World Heritage Site [15].

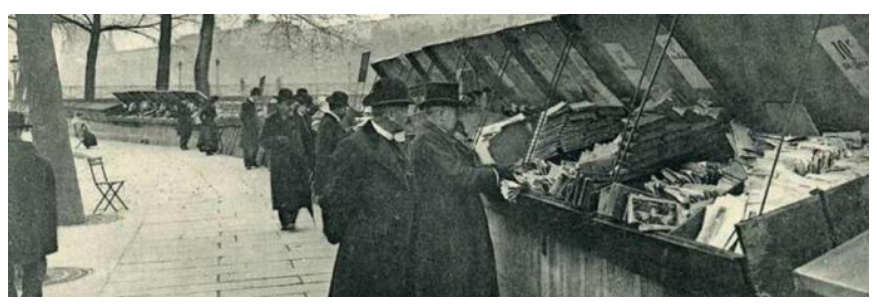

Figure 5. Les Bouquinistes in Paris began in the 1800s.

In 2014; an architect named "Jaime Lerner" designed what he called "Portable Streets". The concept of portable streets is based on the fact that many of today's cities are informal and that ways of integrating formal and informal sectors must be found. Inspired by bouquinistes of Paris, these pieces of street furniture allow street vendors to enjoy quality and comfort, adding a new element to the urban landscape. The idea is flexible and modular. The portable streets offer the potential to boost the local economy and connect communities [16]. When some places in some cities suffers from deterioration, it is not easy to make recovered as people need to live in a liveable streets. This is the main reason to design the portable streets. Fig 6 \& Fig.7 [17].

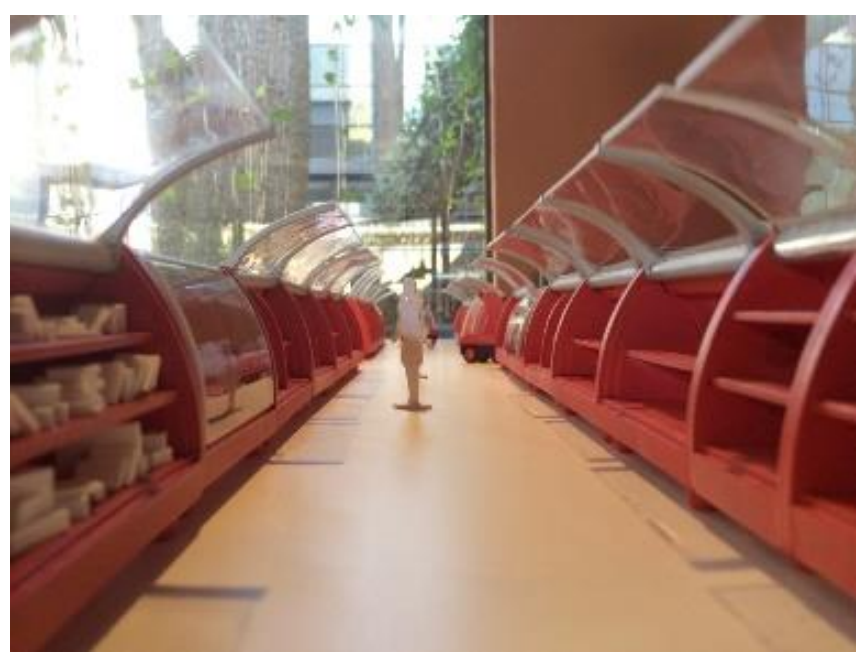

Figures 6. Portable Streets.

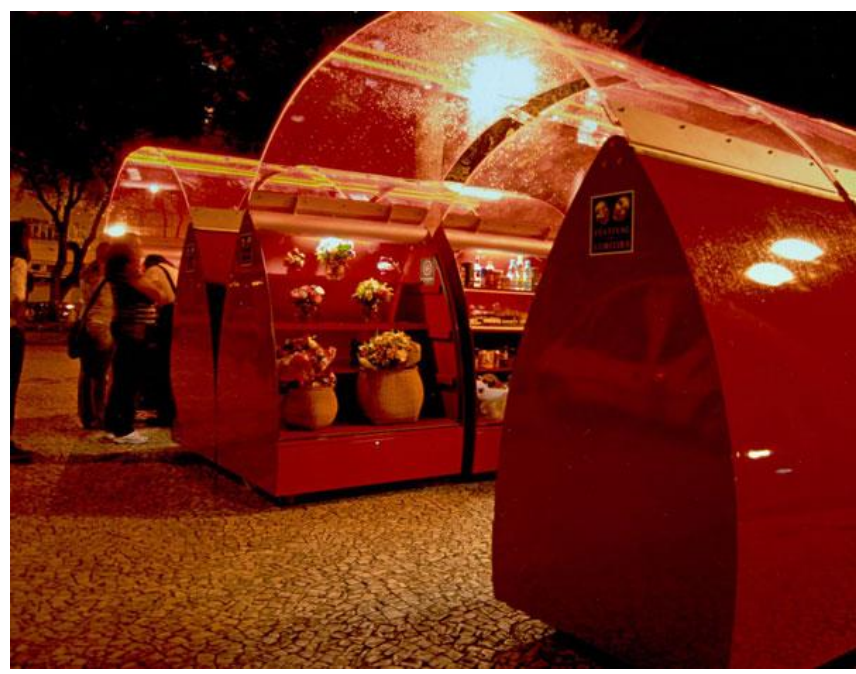

Figures 7. Portable Streets. 


\section{WHAT IS TACTICAL URBANISM}

Various terms are used to describe the movement: tactical urbanism, DIY urbanism, urban hacking, guerilla urbanism, and countless examples of successful projects and strategies ranging from street metamorphosis to vibrant parks to garden initiatives or public art exhibitions [18].

For cities that want to present future capital projects in real-time, the method provides a way to track infrastructure design and evaluate the performance. For non-profit organizations and neighborhood groups, the cost-effective nature of the methodology enables communities to become owners of their built environment and provide a support base for ideas that they want to put into reality [19].

Tactical urbanization focuses on short-term, temporary or experimental programs or interventions to stimulate long-term change. The idea formally emerged at the beginning of the 21 st century at a meeting of the Next Generation of New Urbanists, who were labeled "Lighter, Quicker, Cheaper" [20].

The term "tactical urbanism" was widely used in 2010 2011 when a group of young urban planners founded the publication Tactical Urbanism: Short-term action, longterm change, presenting temporary projects to improve public space in North America. The authors define Tactical Planning as small, short-term interventions to stimulate long-term change. As they mentioned; Tactical Planning has five characteristics as an approach to urban development [21]:

- A progressive and conscious approach to change;

- An offer of local ideas for the challenges of local planning;

- Short-term commitment and realistic expectations;

- Low risks, possibly with a high reward; and

- Developing the social capital of citizens and creating organizational capacities between public/private institutions, non-profit organizations/NGOs and their constituents.

The intentions behind tactical urban development projects are diverse: some projects aim to revive economic recovery, while others aim to improve pedestrian safety and provide citizens with the opportunity to build contacts [21].

These many meanings are reflected in Tactical Town Planning: Short-Term Action for Long-Term Change, a book by American city planners Anthony Garcia and Mike Lydon, two leaders of citizen engagement and principles of The Street Plans Collaborative. Tactical urbanism is simply defined by authors as an approach to creating and activating neighborhoods with short-term, inexpensive and scalable interventions and strategies [16].

\section{CASE STUDTY: STREET 306, DOKKI, EGYPT}

Street 306,_located in Dokki, Fig 8. The project transformed this street into a vital place and an investment project for young people. It is a flagship project of Markets Misr Express for Development and Management, founded by
Tahya Misr, to support youth and small and medium enterprises (SMEs). The project includes 28 units providing about 150 direct job opportunities [22].

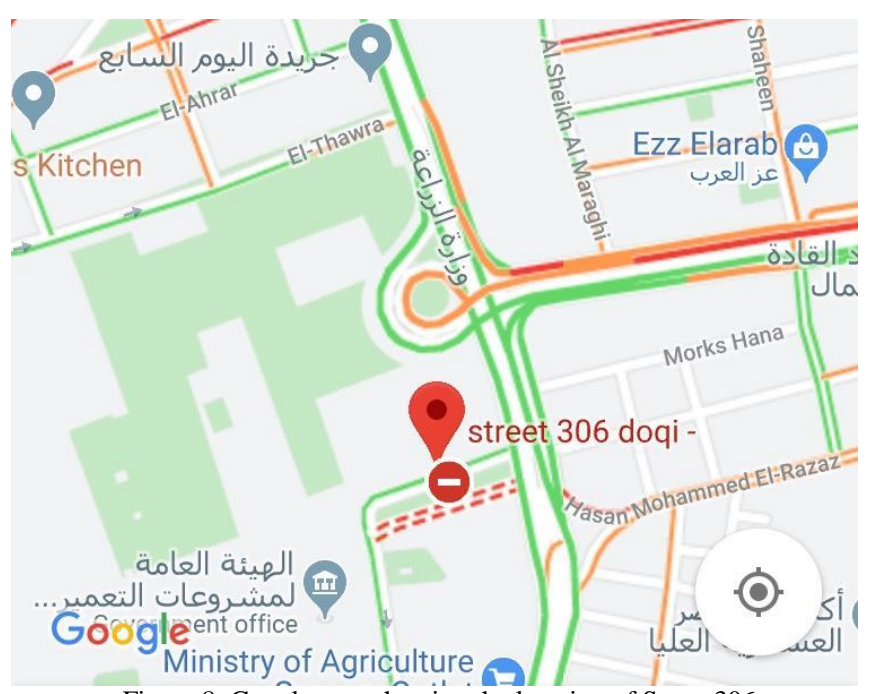

Figure 8. Google map showing the location of Street 306.

\section{A. Project Background}

"Street 306" is a pilot project in all provinces of Egypt. The project aims to bring together young entrepreneurs in the street food sector and other businesses to help create institutions that meet international standards.is a pilot project in all provinces of Egypt. It is an important national economic project, aimed at attracting young people to selfemployment and not waiting for traditional governmental jobs.

Street 306 is not the only one of its type in Egypt; but there are more in other Egyptian locations such as Gharbia, Damietta, and Sheraton. It is planned to open 150 similar projects in various sites. The governorate wants to benefit from this project in many levels, the first; fighting the specter of unemployment with a modern idea, which depends on many European countries, and the second to create recreational communities that allow Egyptian families, to have a leisure walk at the lowest possible prices, especially as a large number of sites 306 Street organizes Entertainment programs, suitable for all classes of society throughout the week, as well as areas for children in all locations..

It is intended that with the completion of the opening of the "306 Street" site, Egypt will have the largest meeting place for food providers in the Middle East [23].

\section{B. Project Analysis}

The street is located in Dokki, in front of the agricultural museum. The location was a residual space for many years. It was a useless green area fenced with a steel fence to prevent pedestrian to pass or use the space.

In order to analyze Street 306 , a regular survey visit to the project has been done by the researcher. There was more than one visit in September and October 2019, and the photos taken are the result of the final visit at 10:30 am on 3 of November 2019. The visit duration was about 1 hour and the 
following photos are recording what the researcher has noticed.

The project has changed the residual space and makes it usable, vital and pleased place despite that the visit was on Sunday morning and there were almost no users. The flagship project represents a recreational place for the community, provides foods, entertainment, and pleasure with a low cost and quick construction period.

The researcher has noticed the following:

1. The project has two opposite entrances located on both sides of the project area. Fig. 9

2. The project uses the Cargotecture concept which depends on reusing the old containers as basic units in the project along with a kind of small kiosks. Fig. 10

3. There is on one side of the entrance to the project unit equipped as public toilets.

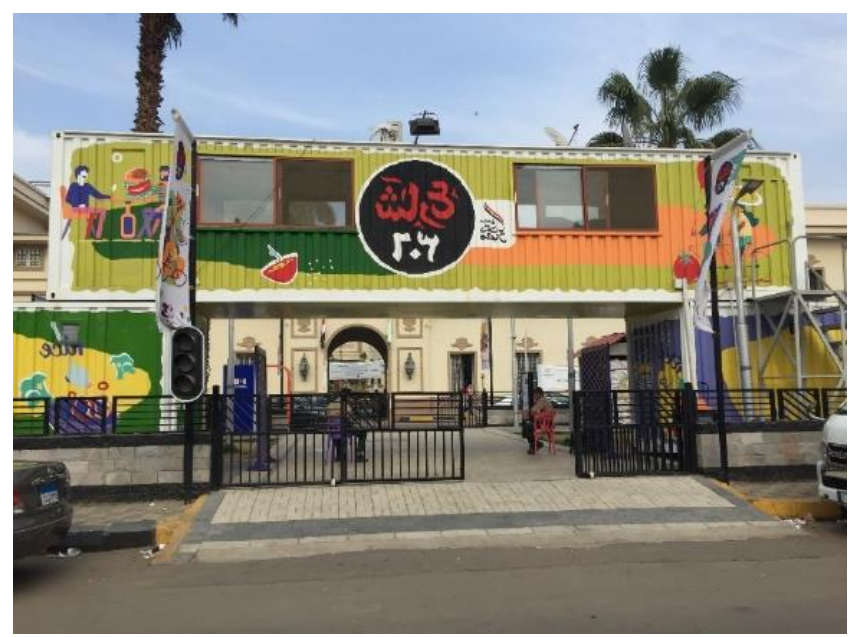

Figure 9. The project has two opposite entrances located on both sides of the project area.

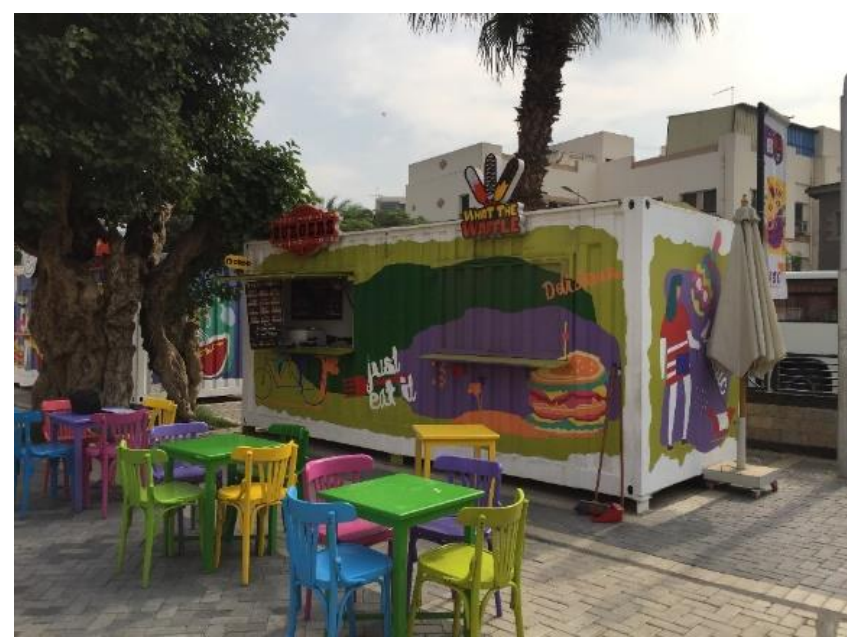

Figure 10. The project uses the Cargotecture concept which depends on reusing the old containers as basic units in the project.

4. The project is served with ATM machines and a number of TV screens. Fig. 12

5. The project is equipped with a large number of colorful wooden seats. Fig. 13
6. There is a dedicated playing area and enjoys good control. Fig. 14

7. As a disadvantage, the project is not served with enough parking space. Fig. 15

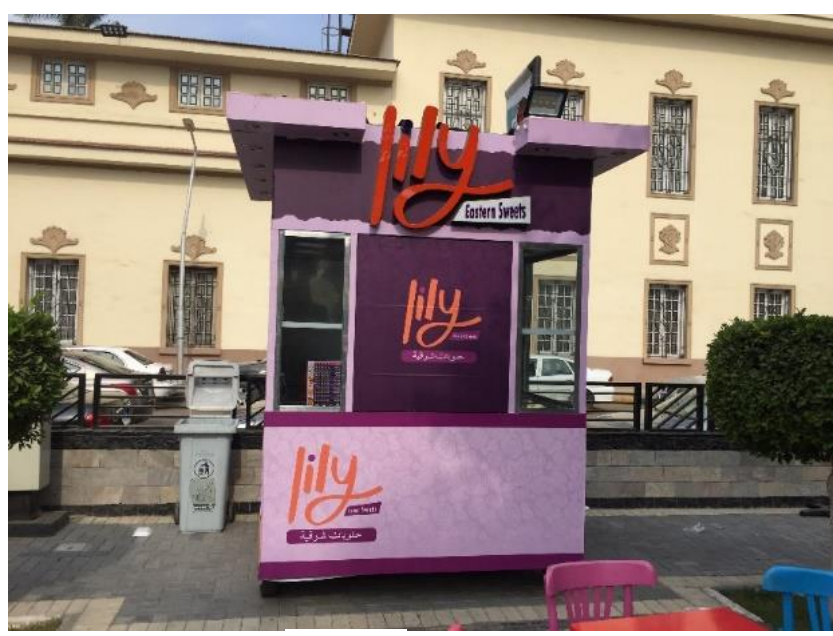

Figure 11. Small kiosks.

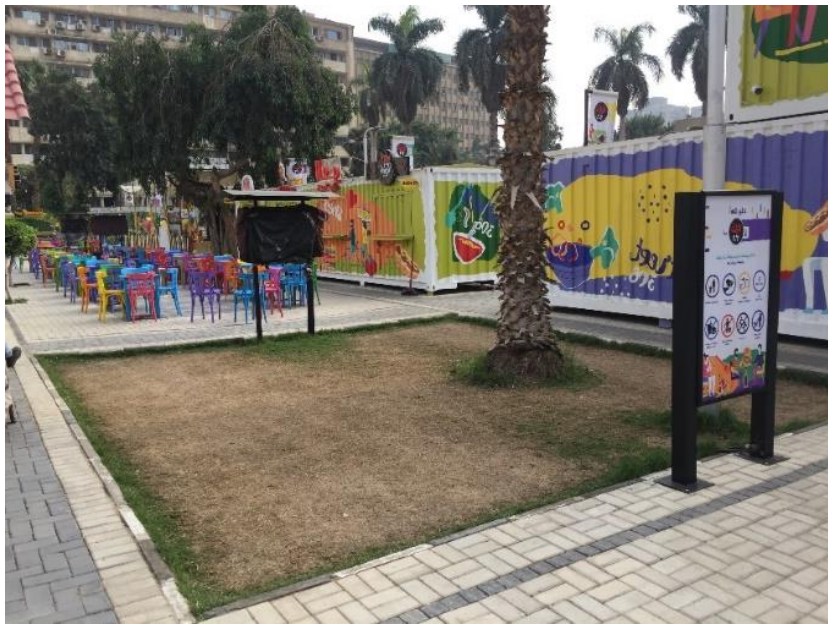

Figure 12. The project is served with ATM machines and a number of TV screens.

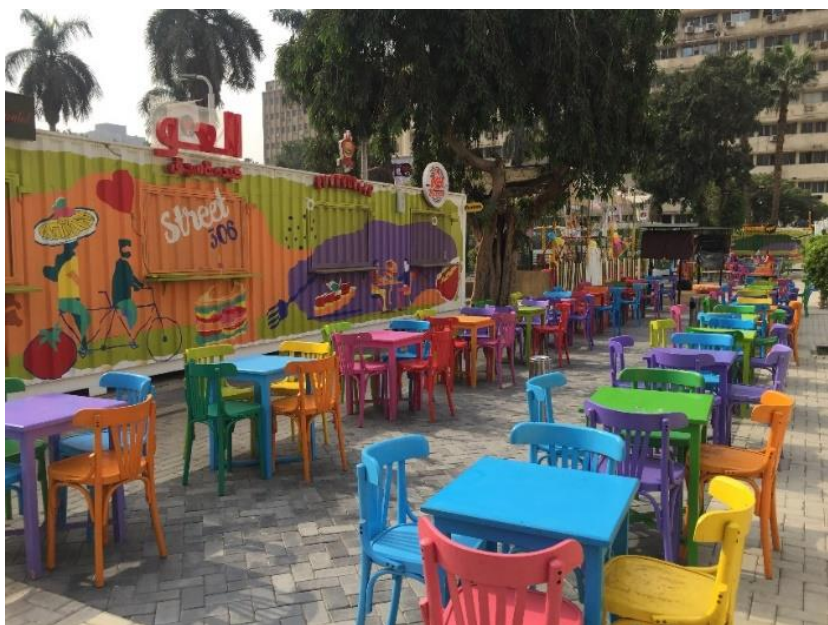

Figure 13. The project is equipped with a large number of colorful wooden seats. 


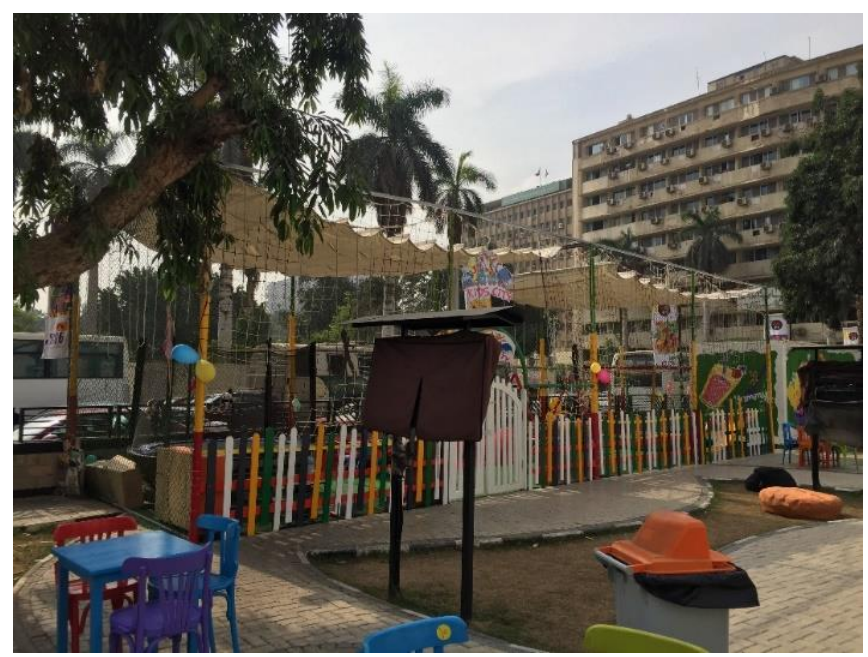

Figure 14. There is a dedicated playing area and enjoys good control.

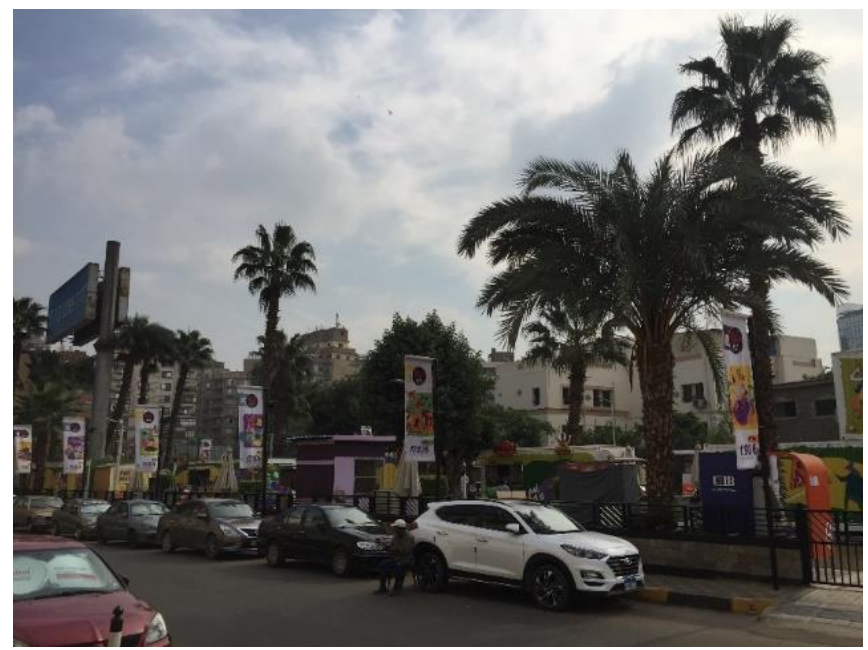

Figure 15. As a disadvantage, the project is not served with enough parking space.

\section{CONCLUSIONS}

Based on the above information and the analysis of the case study, this paper draws several conclusions on different levels regarding the utilization of residual areas using Tactical Urbanism approach and the resulting benefits as follows:

1. Residual spaces have potentials that could be used positively.

2. Although Tactical Urbanism is not a new approach, it is suitable today as a tool for the development of urban environments, especially in developed countries.

3. The importance of benefit from the transformation of residual areas from the informal economy to a formal one.

4. The role of municipalities and governmental agencies as a responsible and protector of the urban areas could be transformed into a partner in such economic projects providing sustainable development needed to raise the quality of life for the communities.
5. Strengthening the image of urban areas and urban tissue by making good places and certain planned areas under control instead of giving the chance to become a sort of slums.

6. Encouraging the income generation for the youth and un-employers by allowing them to have startup projects within the entrepreneur policies frame.

7. Encouraging people to walk by offering them recreational areas in a walkable distance from their homes, in a way that two results could be reached:

- Reduce air pollution by reducing the use of transportation and vehicles.

- A step towards a walkable community.

8. Some areas have a certain problem such as high voltage towers which need to be transferred underground. In this case; owners could have a participatory role in carrying out expenses of embedding the cables.

\section{RECOMMENDATIONS}

1. The use of geographic information programs such as GIS to identify residual spaces in Egypt in order to make an inventory and classification in terms of areas and geographic importance and economic value.

2. Inventory and classification of social activities preferred and appropriate for different spaces.

3. The solution does not always have to be placed for food or entertainment, but projects can also be directed to other activities such as handicrafts and used clothing markets.

4. The need to form a pricing and evaluation committee at the ministry level that follows the municipalities. The tenants could be granted the right to benefit for 25 years with an annual increase and evacuation at the end of the term.

\section{REFERENCES}

1. Campbell, C. (2013). Visualizing Residual Spaces in a new Light. San José State University.

2. Carmona, M. (2010). Contemporary public space, part two: Classification. Journal of Urban Design 15(2): 157-173.

3. Azhar, J., \& Gjerde, M. (2016). Re-Thinking the role of Urban InBetween Spaces. The Architectural Science Association and the University of Adelaide.

4. Winterbottom, D. (2000). Residual Space Re-evaluated. Places, 13(3).

5. Hanson, M. \& Abdulsamad, M. From Pop-Up to Permanent: Five lessons in tactical urbanism. Retrieved from https://globaldesigningcities.org/2018/04/18/from-pop-up-topermanent-five-lessons-in-tactical-urbanism/

6. Franco, J. Toward a Definition of Urban Spaces. Retrieved from https://arqjespalfra.wordpress.com/toward-a-definition-of-urbanspaces/

7. Osoria Emil, 2012. "In-between Spaces in Antofagasta relationship of Architecture to its context", 10-13. Print

8. https://www.youm7.com/

9. Doron, G. 2006. "The derelict land and the elephant." Library 1(1): 10-23.

10. Pfeifer, L. 2013. "The Planner's Guide to Tactical Urbanism", 65. 
11. Berg, N. The Official Guide to Tactical Urbanism. March 2 , 2012. Retrieved from https://www.citylab.com/design/2012/03/guide-tacticalurbanism/1387/

12. Shackelford, K. (2014, Feb.). Tactical Urbanism: A Movement on the Rise. Retrieved from www.peoriamagazines.com: http://www.peoriamagazines.com/ibi/2014/feb/tactical-urbanism

13. Bradley, S. How Tactical Urbanism "Adds Up”. 20 July 2015. Retrieved from https://www.thenatureofcities.com/2015/07/20/how-tacticalurbanism-adds-up/

14. Elshater, Abeer. (2014). Tactical Urbanism: A Method of Community Empowerment in Cairo Neighborhoods. World SB 14, Barcelona.

15. Lydon, M., et al. (2012). Tactical Urbanism 2: The Street Plans Collaborative.

16. Priestmangoode. Portable Streets - Jaime Lerner Arquitetos Associados. October 1, 2014. Retrieved from https://brightideastomakelifebetter.wordpress.com/2014/10/01/po rtable-streets-designed-by-jaime-lerner-arquitetos-associados/

17. Green, J. Interview with Jaime Lerner. Retrieved from https://www.asla.org/ContentDetail.aspx?id=30875

18. Barista, D. Tactical urbanism: Why bigger isn't always better in urban revitalization. May 27, 2015. Retrieved from https://www.bdenetwork.com/blog/tactical-urbanism-why-biggerisn\%E2\%80\%99t-always-better-urban-revitalization

19. Moskerintz, H. Tactical Urbanism for Placemaking. January 23, 2019. Retrieved from https://www.nar.realtor/blogs/spaces-toplaces/tactical-urbanism-for-placemaking

20. Colinday. Placemaking, Tactical Urbanism, \& the Struggle for Community Identity. 21 Mar, 2018. Retrieved from https://blog.ibe.colostate.edu/2018/03/21/placemaking-tacticalurbanism-the-struggle-for-community-identity/

21. Pfeiferm, L. (2013). The planner's Guide to Tactical Urbanism. Retrieved from https://reginaurbanecology.files.wordpress.com > 2013/10 > tuguide

22. Trancik., R. 1986. "Finding lost space; Theories of urban design", 1st ed.; John Wiley \& Sons.

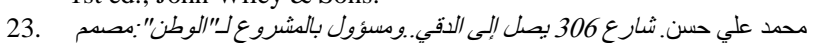
بمعايير أوروبية. الجمعة 04 أكتوبر 2019.

https://www.elwatannews.com/news/details/4364509 